European Journal of Accounting, Auditing and Finance Research

Vol.8, No.1, pp.30-51, January 2020

Published by ECRTD-UK

Print ISSN: 2053-4086(Print), Online ISSN: 2053-4094(Online)

\title{
WORKING CAPITAL MANAGEMENT FIRM LIQUIDITY AND STOCK MARKET SEASONALITY: EVIDENCE FROM NIGERIA
}

\author{
Peter E. Ayunku \\ Department of Banking and Finance, Niger Delta University, Wilberforce Island, Bayelsa State, \\ Nigeria.
}

\author{
Ekokeme, Tamaroukro Timipere \\ University of Africa, Toru-Orua, Sagbama, Bayelsa State, Nigeria \\ Corresponding Email Address: timiwealthy@yahoo.com
}

\begin{abstract}
This study examines the relationship between Working Capital Management Firm Liquidity and Stock Market Seasonality among quoted firms in Nigeria. Six hypotheses were formulated following the dependent variable of Stock Market Liquidity. The independent variables employed for this study include: Liquidity Ratio, Account Payable Day, Account Receivable Day, Inventory Day, Firm Leverage and Firm Size. This study is based on ex-post facto research design and employed a panel data set collected Fifty (50) non-financial companies over an eight year period ranging from 2011 to 2018 financial year. We analyzed the data set using descriptive statistics, correlation and Panel Ordinary Least Square Regression Analysis. Our finding lends credence to the efficient market theory which holds that share markets prices are unpredictable and as such cannot be forecasted. Specifically, the finding suggests that market liquidity cannot predict stock market returns irrespective of the season of the year. Hence, we carefully hold that the stock market in Nigeria is efficient due to its randomness and will rapidly respond to any information or anomalies presented to it. The study recommends among others that policy makers in emerging markets such as Nigeria should ease entry barriers for prospective firms so as to enhance liquidity. The study further recommends that, proper inventory management system should be put in place in order to avoid working capital mismanagement.
\end{abstract}

KEYWORDS: working capital, management, firm, liquidity, stock market, seasonality, Nigeria

\section{INTRODUCTION}

Working capital management is a very important component of corporate finance because it directly affects the liquidity and profitability of the firm. Specifically, it deals with current assets and current liabilities. Working capital management is important due to several reasons: for instance, the current assets of a typical manufacturing company accounts for over half of its total assets while for a distribution company, current assets account for even more. Excessive levels of current assets can easily result in a firm's realizing a substandard return on investment. However firms with too few current assets may incur shortages and difficulties in maintaining smooth operations (Horne and Wachowicz, 2000). Hence, efficient working capital management in relation to account payables, account receivables, and inventories involves planning and 
European Journal of Accounting, Auditing and Finance Research

Vol.8, No.1, pp.30-51, January 2020

Published by ECRTD-UK

Print ISSN: 2053-4086(Print), Online ISSN: 2053-4094(Online)

controlling these operations in a manner that eliminates the risk of inability to meet due short term obligations on the one hand and avoid excessive investment in these assets on the other hand (Eljelly, 2004).

Corollary to working capital management is firm liquidity management knowing so well that stock operations may affect economic activities through the creation of liquidity. Many profitable investments require a long-term commitment of capital, but investors are often reluctant to relinquish control of their savings for long periods. Liquid equity markets make investment less risky--and more attractive--because they allow savers to acquire an asset--equity--and to sell it quickly and cheaply if they need access to their savings or want to alter their portfolios. At the same time, companies enjoy permanent access to capital raised through equity issues. By facilitating longer-term, liquid markets improve the allocation of capital and enhance prospects for long-term economic growth. Furthermore, by making investment less risky and more profitable, firm liquidity can also lead to more investment. Put succinctly, investors will come if they can leave (Levine 1996). Recognized as one of the most instrumental properties of an efficient financial market, liquidity is referred to as the ability to trade large volumes of assets quickly at low cost and as at when required (Harris 2003). Furthermore, for the ongoing firm, liquidity is not reliant on the liquidation value of its assets, but rather on the operating cash flows generated through efficient working capital management (Soenen, 1993).

Studies have documented abundant evidences that working capital management of a firm in part affects and firm liquidity affects firm profitability through costs of equity, returns and valuations, trading activities, investment strategies, risk management, market stability and economic growth (Pástor \& Stambaugh 2003; O'Hara 2004; Acharya and Pedersen 2005; Butler, Grullon \& Weston 2005; Chordia, Roll and Subrahmanyam 2008) Although most of these studies and discussions on various aspects and dimensions of working capital management and liquidity have been well documented, the precise sources of variation in market liquidity in terms of seasonality have not been sufficiently researched and understood.

\section{Statement of Problem}

Nigeria is an emerging economy and it is gradually gaining in quality and efficiency in its stock market performance (Enweremadu, 2013). The behavior of emerging markets is changing significantly over time with respect to their degree of integration with the global economy (Bekaert and Harvey 2000). Emerging from recession in the second quarter of 2017, Nigeria witnessed a rebound in investment activities which saw the Nigerian Stock Exchange market recover from macroeconomic overhang of the commodity down-cycle, to become the third best performing market of 2017 globally (Nigerian Stock Exchange 2017). However, comprehensive studies of working capital management and stock market liquidity in the context of emerging markets are still very limited primarily due to the insignificant size of the markets compared to global equity markets. 
European Journal of Accounting, Auditing and Finance Research

Vol.8, No.1, pp.30-51, January 2020

Published by ECRTD-UK

Print ISSN: 2053-4086(Print), Online ISSN: 2053-4094(Online)

Indeed, existing academic literature lacks clear answers as to why liquidity and firm specific working capital management tools in the stock markets tends to anomalously increase or decrease in some specific times of the year, and why it shows regular seasonal pattern. (Kramer, Kamstra, and DeGennaro 2005) have documented seasonality in overall market liquidity. (Eleswarapu and Reinganum 1993), (Hasbrouck 2005), and (Hong and Yu 2005) find that average stock liquidity changes seasonally. Additionally, (Amihud and Mendelson 1986), (Brennan and Subrahmanyam 1996), and (Easley, Hvidkjaer, and O'Hara 2002) show stocks that are illiquid in a particular period subsequently have high average returns.

Despite the fact that there have been some attempts to propose possible explanations for the aforementioned seasonality puzzle, there are many unanswered questions concerning the determinants of seasonality in the stock market. Ambiguity in the existing results and lack of clear answers makes us believe that there is a room and need for new evidence particularly in the context of a developing country such as Nigerian. Furthermore, there is scanty evidence among various studies carried out on market anomalies of listed companies in Nigeria.

Ajibola and Nwakanma, 2014; Alagidede, 2008; Oladayo, 2015; Olowe, 2011; Osazevbaru and Oboreh, 2014; Umar, 2013 all of which have failed to address stock market returns in a seasonal context providing a research gap which this study tends to fill. Furthermore, to the best of the researchers' knowledge, no study is known within the Nigerian context to extensively model seasonality in stock liquidity for a sample of non-financial listed companies in Nigeria. It is against this backdrop that this research attempts to uncover the impact of working capital management, and firm liquidity on stock market seasonality (stock returns) using data set from the Nigerian stock exchange market.

\section{REVIEW OF RELATED LITERATURE}

A large number of studies have documented the existence of return anomalies around specific calendar events and around cultural festivities. For example, using data from NYSE and AMEX from 1963 to 1979, (Keim 1983) found higher abnormal returns in January particularly during the initial weeks than the rest of the year, where small firms generated higher abnormal returns relative to large firms. The result also shows that size effect was stronger in January. He argued that the findings appeared to be unrelated neither with tax loss selling hypothesis nor with financial information event hypothesis.

(Ajobola and Nwakanma 2014), investigated market anomalies using 140 listed companies in the Nigerian equity market. They employed both the parametric and non-parametric methodology. Using the normal error distribution assumption with GARCH and TGARCH model, they concluded that there is a significant market anomaly in the Nigeria stock exchange. Other nonparametric methods used are the Lilliefors, Crammer-Von-Mises, and the Anderson-Darling tests. 
European Journal of Accounting, Auditing and Finance Research

Vol.8, No.1, pp.30-51, January 2020

Published by ECRTD-UK

Print ISSN: 2053-4086(Print), Online ISSN: 2053-4094(Online)

(Umar, 2013), investigated the day-of-the-week effects for the Nigerian and South African equity markets for pre-liberalization and post-liberalization periods. The exponential generalized autoregressive conditional heteroskedasticity (EGARCH) model was used to estimate the day-ofthe-week effect both in the mean and variance equations. Evidence of day-of-the-week effect was found in both the mean and variance equation for the Nigeria and South African equity markets.

In the context of working capital management and firm performance, Falope and Ajilore (2009) found no significant variations in the effects of working capital management between large and small firms in Nigeria using a sample of 50 quoted companies.

Dong and tyh-tay-su (2010) documented a study to find out the relationship between working capital management and profitability. They considered gross operating profitability as a dependent variable and account receivable ratio in number of days, account payable ratio in number of days, inventory turnover ratio in number of days, and cash conversion cycle as independent variables. Size of the firms, debt ratio and fixed assets to total assets were control variables. They found that there is a negative relationship between account receivable, inventory days and profitability. But there is a positive relationship between account payable and firm profitability.

(Osazevbaru and Oboreh 2014) investigated the Nigerian stock market anomalies using the OLS methods and the GARCH model under the normal error distribution assumption with data spanning from January 1995 to December 2009. They found anomaly in the Nigerian stock market for Monday effects. Using one hundred and sixty-seven (167) stocks, all share index, January and Monday effect, for firms listed on the Nigerian stock market (NSE-ASI) between the period of 2004 and 2014, the study found no significant evidence in January and day-of-the-week effect.

(Olowe 2014) investigated day-of-the-week effects in the Nigerian foreign exchange market using the GARCH and GJR-GARCH models under the normal error distributional assumption for the period of January 2nd 2002 to March 13th 2009. Although the results failed to support the presence of the day-of-the-week in the FOREX rate returns, but there was evidence of the effects in the volatility.

Zariyawati, Annuar, Taufiq, and Rahim (2009) uncovered the relationship between working capital management and corporate performance. They employed panel data of 1628 observations from the period of 1996 to 2006 of six sectors listed in Bursa Malaysia. Employing different variables like Profitability as a dependent variable, and the independent variables of working capital management measured by cash conversion cycle, number of days account receivable, number of day's inventory and number of days account payable, found that there is a negative significant relationship between cash conversion cycle and profitability of firms.

(Oladayo 2015) investigated the existence of calendar anomalies on 167 stocks listed on the Nigerian stock exchange ("NSE") between the period 2004 and 2014. The simple Ordinary Least Squares ("OLS") estimation technique and the Generalized Autoregressive Conditional 
European Journal of Accounting, Auditing and Finance Research

Vol.8, No.1, pp.30-51, January 2020

Published by ECRTD-UK

Print ISSN: 2053-4086(Print), Online ISSN: 2053-4094(Online)

Heteroscedasticity (“GARCH”) model were utilized to test for day of the week effects and any other monthly calendar anomaly that has been reported at different times on the Nigerian Stock Exchange. Evidence from this study indicates that, there was no statistically significant day of the week or month of the year effect. There is no evidence of a January effect or any other monthly effects.

(Kithii 2008) studied the relationship between working capital management and profitability of companies listed on the Nairobi Stock Exchange for a sample of 24 firms during a 6 year period ranging from 2001 to 2006. The data set was analyzed using ordinary least square regression analysis. The findings show that managers could create profits for their companies which will result to higher returns by keeping each different component of working capital management (accounts receivables, accounts payables and inventory) at an optimal level.

(Osarumwense 2015) assesses the influence of error distributional assumption on appearance or disappearance of day-of-the-week effects in returns and volatility using data from the Nigerian stock exchange (NSE-30). The Gaussian, Student-t, and the generalized error distribution were incorporated in the $\operatorname{GARCH}(2,1)$ and $\operatorname{EGARCH}(2,1)$ models. Result reveals that day-of-theweek effects are sensitive to error distribution.

(Ajibola, Prince and Lenee 2014) presented a robust analysis of the Nigerian equity market using weekly stock prices of 140 quoted companies in Nigeria over the period of Jan 12006 to Dec 27 2012. The study adopted two sets of tests. The first set comprises Llliefors, Cramer-Von-Mises, Anderson-Darling and Ljung-Box which confirmed that stock prices are not normally distributed. But the second set includes size/rank variance ratio tests and TGARCH in-Mean technique. The tests jointly revealed strong presence of inefficiency as anomalies can be traced to persisted volatility, lack of randomness, significant effects of information and heteroskedasticity/leptokurtic nature of stock prices.

(Chordia, Sarkar and Subrahmanyam 2005) investigate the liquidity dynamics across equity and bond markets as well as the impact of monetary policy on liquidity. Consistent with previous studies, their results show that market return (volatility) is negatively related to market illiquidity and there is a day of the week effect on both markets' liquidity. They also find that relaxed monetary policy results in high stock market liquidity

(Raheman and Nasr 2007) while studying the relationship between working Capital Management and stock returns of Listed Firms in Pakistani employed a sample of 94 Pakistani firms listed on Karachi Stock Exchange for a period of 6 years ranging from 1999 to 2004. The study used regression analysis to find coefficient estimates and found out that there is a strong negative relationship between variables of the working capital management and stock returns of the firm.

(Van Ness, Van Ness and Warr 2005) found consistent results where liquidity has persistent patterns related to the days-of-the-week effects, with Tuesdays having the highest liquidity and 
European Journal of Accounting, Auditing and Finance Research

Vol.8, No.1, pp.30-51, January 2020

Published by ECRTD-UK

Print ISSN: 2053-4086(Print), Online ISSN: 2053-4094(Online)

Fridays having the lowest liquidity during the weeks. This days-of-the-week effect and the holiday effect have also been observed in the bond market implying a similar pattern of behaviour in the equity market as well as the debt market.

With regard to cultural seasonality of liquidity, (Białkowski, Etebari and Wisniewski 2012) reported that eleven Islamic countries (that is, Egypt, Jordan, Kuwait, Malaysia, Morocco, Oman, Pakistan, Qatar, Tunisia, Turkey and United Arab Emirates) provided higher average return during Ramadan than the rest of the year between 1989 and 2007. Using the Morgan Stanley Capital International (MSCI) index, the study found that investors were able to realize on average 38.09\% annualized return in dollar value, compared to $4.32 \%$ for the rest of the year. The results using the S\&P index produces consistent results, with average annualized returns of $40.77 \%$ during Ramadan and $11.87 \%$ during the other months.

(Chordia, Roll and Subrahmanyam 2001), investigate daily market liquidity for NYSE using measures of spread, depth and trading activity over an 11 year period. They find that market liquidity is affected by market returns, volatility and interest rate variables. They also find that market liquidity drops significantly on Fridays, around holidays and increases prior to the announcement of macroeconomic variables. Consistent with (Chordia et al. 2001), (Fujimoto 2003) also finds that daily variation in market liquidity is related to market returns and volatility.

Hornbrink and Bratland (2013) studied the relationship between working capital policies and stock performance on the Swedish stock market for the period 2009 to 2012 . The results of this study showed no clear relationship between Swedish firm's working capital policy and stock return, working capital policy had some effect on the volatility of stocks. The study concluded that working capital policy plays a part in firm's stock performance across different sectors even though there was no clear pattern.

Bammeri and Dehani (2013) also studied the effect of working capital management on stock returns of companies in Tehran Stock Exchange. Examining 112 listed companies for the period 2002 to 2011, the results showed that there was no significant relationship between accounts receivable collection period and stock returns, accounts payable payment period and stock return and also between cash conversion cycle with stock returns but revealed that there was a significant relationship between goods inventory cycle period and stock returns.

\section{METHODOLOGY}

\section{Study Design}

The study will adopt a descriptive survey design. Such a research design is used to obtain information concerning the current state which describes what exists in respect to variables or conditions in a situation. This approach involves gathering data that describes events and then organizes, tabulates, depicts and describes the data. It enables the researcher to obtain adequate information and identify variables and hypothetical constructs used to test theories. This method is 
European Journal of Accounting, Auditing and Finance Research

Vol.8, No.1, pp.30-51, January 2020

Published by ECRTD-UK

Print ISSN: 2053-4086(Print), Online ISSN: 2053-4094(Online)

considered appropriate because the study involved interacting with the population of interest for them to describe liquidity and working capital effects on stock market seasonality (trend or anomalies) for non-financial companies listed on the Nigerian Stock Exchange.

\section{Sources of Data}

The nature of this study necessitates the use of secondary data. Annual report of the sampled companies is used in collecting the data for this study, due to its degree of reliability and widespread acceptability by organizational stakeholders (Deegan and Rankin, 1997; Haniffa and Cooke, 2005). The final compilation of the data set was carried out by Machame Ratios a registered company in Nigeria responsible for collating and ware housing companies' data suitable for carrying out regression analysis.

\section{Sample and Sampling Techniques}

The sample size will cover all firms contained within the group of non-financial companies on the Nigerian stock exchange market as at 2017. From this sample, companies with unavailable data for this particular study as at the time of collecting the data are removed to arrive at a final sample of 50 companies drawn from: ICT, Conglomerates, Manufacturing, Services, Oil \& Gas, Health Care, Construction and Agro sectors of Nigeria. The simple random sampling technique was adopted for the purpose of selecting such a sample from the population and deemed appropriate based on the scientific guideline for determination of samples as developed by Krejcie and Morgan, 1970.

\section{METHOD OF DATA COLLECTION}

The method of data collection for this study involves handpicking the relevant data (figures) corresponding to the variables of interest of the study. This data set is then keyed into Microsoft Excel data sheet for further computation and compilation. The entire dataset were collected from annual financial statements and the Nigerian stock exchange fact book 2017.

\section{Tabular Operationalization of Variables}

\begin{tabular}{|l|l|l|}
\hline Variable & Measurement & Sources \\
\hline $\begin{array}{l}\text { January to December Stock } \\
\text { Prices Returns } \\
\text { (Dependent variables) }\end{array}$ & $\begin{array}{l}\text { Aggregate Closing Share } \\
\text { Prices for the 12 calendar } \\
\text { months of the year }\end{array}$ & Odhiambo, 2012 \\
\hline $\begin{array}{l}\text { Current Ratio } \\
\text { (Independent variable) }\end{array}$ & $\begin{array}{l}\text { Current asset ratio in in } \\
\text { percentages is computed as } \\
\text { current asset divided by Total } \\
\text { asset }\end{array}$ & $\begin{array}{l}\text { McGuigan 2009 Bouman and } \\
\text { Jacobsen 2002 }\end{array}$ \\
\hline $\begin{array}{l}\text { Inventory Days } \\
\text { (Independent variable). }\end{array}$ & $\begin{array}{l}\text { Inventory Days is computed } \\
\text { as inventory divided by cost } \\
\text { of goods sold multiply by } \\
1 / 365 .\end{array}$ & Bhaduri, 2002 \\
\hline Payable Days & \multicolumn{2}{|l}{} \\
\hline
\end{tabular}


Print ISSN: 2053-4086(Print), Online ISSN: 2053-4094(Online)

\begin{tabular}{|l|l|l|}
\hline (Independent variable). & $\begin{array}{l}\text { Payable Days is computed as } \\
\text { Trade payable or trade } \\
\text { creditors days divided by cost } \\
\text { of goods sold multiply by } \\
1 / 365 .\end{array}$ & \\
\hline $\begin{array}{l}\text { Receiveable Days } \\
\text { (Independent variable). }\end{array}$ & $\begin{array}{l}\text { Receivable Days is computed } \\
\text { as Trade receivable or trade } \\
\text { debtors divided by revenue or } \\
\text { sales multiply by } 1 / 365 .\end{array}$ & $\begin{array}{l}\text { Raheman and Nasr } 2007 \\
\text { Ajibola, Prince and Lenee }\end{array}$ \\
\hline Firm Leverage & $\begin{array}{l}\text { Debt to Total Asset in } \\
\text { percentages is computed as } \\
\text { total liabilities divided by } \\
\text { Total asset }\end{array}$ & Bammeri and Dehani 2013 \\
\hline
\end{tabular}

\section{Method of Data Analysis}

In this study, the secondary data set that were collected was analyzed using descriptive statistics, correlation matrix and regression analysis. The descriptive statistics is used to evaluate the characteristics of the data: Mean Maximum, Minimum, and Standard Deviation and also check for data normality. The correlation analysis is used to evaluate the relationship between the variables and to check for multicollinearity. Panel Ordinary Least Square Regression Analysis is employed to evaluate the effect of the independent variables on the dependent variables. It also reveals the degree of influence and effect which the independent variables have on the dependent variable.

\section{Model Specification}

In the light of the methodological knowledge gathered and following the review of empirical literature in our previous chapter, a panel data multiple regression model is specified. The model for the study is premised on the main objective and anchored on the sub-objective. Hence, following the method of Fama and French (1992) which has been used widely in previous studies (Aitken \& Comerton-Forde 2003; Beaver \& Ryan 2000; Datar., Naik and Radcliffe 1998), we provide an empirical model for the study with control variables of firm size and firm leverage, as follows:

\section{Seasonality Model}

Stock Market Seasonality $=f$ (liquidity + inventory day + account payable day + account receivable day + leverage + firm size) (1)

However, relating equation one above in an econometric form, we have: 
marrtns $_{i t}=\partial_{0}+\partial_{1}$ curratio $_{i t}+\partial_{2}$ invtday $i t+\partial_{3}$ payday $_{i t}+\partial_{4} \partial$ Irecday $_{i t}+\partial_{5}$ leverage $_{i t}+$ $\partial_{6} f$ size $+\Pi_{i t}$

junertns $_{i t}=\beta_{0}+\beta_{1}$ curratio $_{i t}+\beta_{2}$ invtday ${ }_{i t}+\beta_{3}$ payday $y_{i t}+\beta_{4}$ recday $_{i t}+\beta_{5}$ leverage $\mathrm{e}_{i t}+$ $\beta_{6}$ fsize $+\Pi_{i t}{ }^{\prime \prime}$

septrtnsit $_{i j}=\delta_{0}+\delta_{1}$ curratio $_{i t}+\delta_{2}$ invtday $y_{i t}+\delta_{3}$ payday $_{i t}+\delta_{4}$ recday $_{i t}+\delta_{5}$ leverage $_{i t}+$ $\delta_{6} f$ size $+\Pi_{i t}$

decrtns $_{i t}=a_{0}+a_{1}$ curratio $_{i t}+a_{2}$ invtdayit $+a_{3}$ payday $y_{i t}+a_{4}$ recday $_{i t}+a_{5}$ leverage $\mathrm{e}_{i t}+$ $0_{6} f$ size $+n_{i t}$

Where;

mantns = Season 1 (March Stock Retums)

junertns $=$ Season 2 (June Stock Retums)

Septrtns $=$ Season 3 (September Stock Retums)

Decrtns = Season 4 (December Stock Retums)

Curratio = Liquidity

Invtday = Inventory Day

Payday = Account Payable Day

Recday = Account Receivable Day

Leverage $=$ Leverage

Fsize $=$ Fim Size

$\partial_{0}, \beta_{0}, \delta_{0}, \alpha_{0}=$ constants

$\partial_{1}$ to $\partial_{6}$

$\beta_{1}$ to $\beta_{6}$

$\delta_{1}$ to $\delta_{6}$

$q_{1}$ to $\alpha_{6 n}$ coefficient to be estimated

$\pi_{i t}=$ error tems over the cross section and time.

$i t=$ cross section of listed companies time variant 
European Journal of Accounting, Auditing and Finance Research

Vol.8, No.1, pp.30-51, January 2020

Published by ECRTD-UK

Print ISSN: 2053-4086(Print), Online ISSN: 2053-4094(Online)

\section{ECONOMETRIC RESULTS}

\section{Table 4.1 Descriptive Statistics}

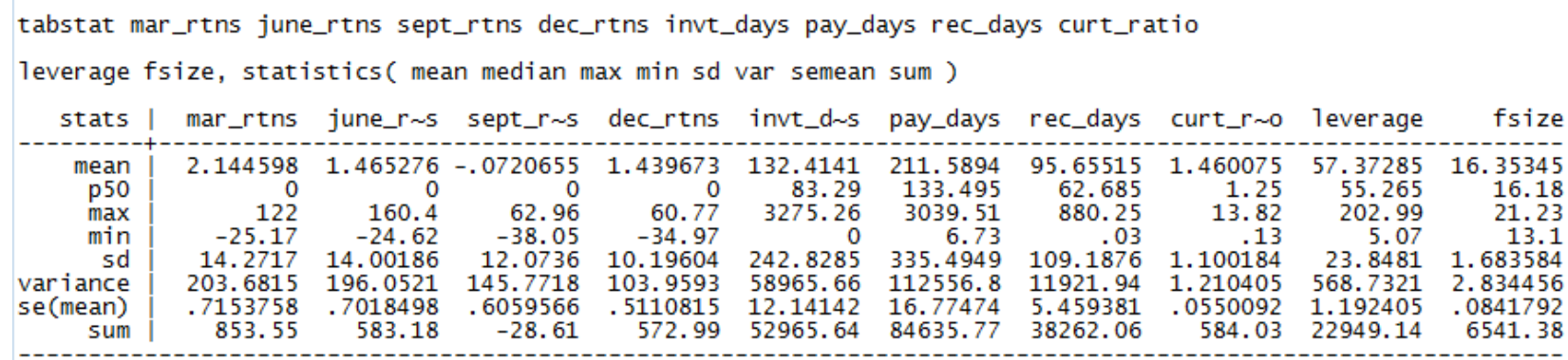

Table 4.1 above shows the mean (average) for each of the variables, their maximum values, minimum values, median, standard deviation, variance, standard error of mean, and the sum statistics of the data set used in the study. The result provided some insight into the nature of the selected companies' adopted for the study.

Following the results obtained from the descriptive statistics, we observed that on the average, the sampled firms held stock for a period of three months and it also took about three months for due payments to be made to creditors. In relation to the average time which creditors utilized in responding to debts, the statistics suggest that on the average, receivables was realized after only sixty-three days for the sampled firms during the period under review.

Furthermore, we observed that within the period under review, stock returns for season one (mar_rtns) had a minimum price of -25.17 and reached a height of 122 between the period of January and March for the scope under review. The statistics also reveal that during quarter two, (April to July) there was a slight improvement in stock returns as it was observed that the price made a move from lowest depth of -24.62 to highest high of 160.4 signaling a return of over a $100 \%$ positive change during both seasons under consideration. From the statistics analysis, it is revealed that the minimum returns for both seasons three (July to September, -38.05) and four (August to December -34.97) were deeper than the returns obtained during the first two quarters of the year. This may be seen as the 'October effect' theory which postulates that equities tend to decline in October because investors get jittery at the historical precedent of market crashes occurring in said month.

Again, the results reveal that during the four seasons under analysis, season two out performed in terms of returning gains to investors while season four underperformed which may go a long way to confirm the October effect hypothesis of stock returns. In relation to the sampled companies that out performed in terms of returning gains to shareholders, the statistics show that Transcorp Nig. Plc, May \& Baker Nig. Plc, Thomas Wyett Plc, and Air Logistics Plc secured the most prices for Season1, 2, 3, 4 respectively. (See Appendix2 for details). Overall, the statistics reveals a decaying effect/experience in stock returns between January and December for the period under study. 
European Journal of Accounting, Auditing and Finance Research

Vol.8, No.1, pp.30-51, January 2020

Published by ECRTD-UK

Print ISSN: 2053-4086(Print), Online ISSN: 2053-4094(Online)

Furthermore, we find that the variable of liquidity measured as current ratio which also connote a rough estimate of a company's financial health suggest that on the average the sampled companies are financially healthy since the average current ratio railed around 1.5 during the period under analysis. This implies that the sampled companies were capable of paying their short-term obligations in due time. However, among the sampled companies, it is revealed that Curtix Nig. Plc (13.82) and Thomas Wyett Plc. (0.13) had the best and worse current ratios respectively during the period under study.

\section{Correlation Analysis}

In Table 4.2 below, the study focuses on the correlation between the four variables of stock market seasonality and the individual explanatory variables. Simple linear correlation is a measure of the degree to which two variables vary together, or a measure of the intensity of the association between two variables. The purpose of correlation analysis is to measure and interpret the strength of a linear or nonlinear (eg, exponential, polynomial, and logistic) relationship between two continuous variables. In conducting the correlation analysis for this study, the Karl Pearson's coefficient of correlation is employed.

Correlation

Matrix

Table

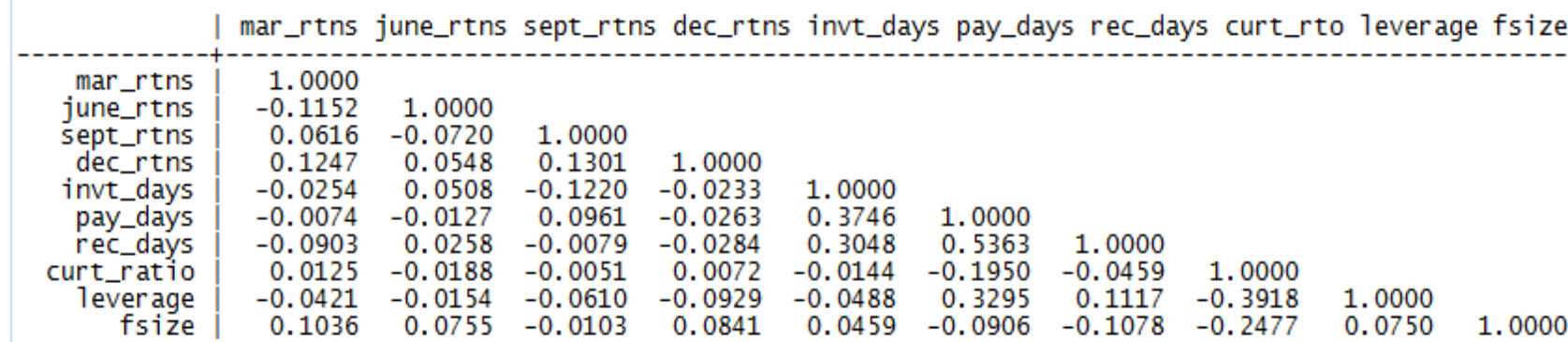

From the results above, we observed that season1 as depicted by mar_rtns is negatively and weakly associated with season 2 june_rtns $=-0.115$ showing a $15 \%$ association. Furthermore, season1 showed a positive and weak association with season 3 (sept_rtns) $=0.061$ i.e. 6\% association level. It is worthy to note that no variable of interest showed a high association with another variable. Lastly from the descriptive statistic, it is revealed that the test for normality or the existence of outlier or extreme value among the variables shows that all the variables are normally distributed. This is evident from the significant values recorded by the Prob $>\mathrm{chi}^{2}$ as shown in the table below. 
European Journal of Accounting, Auditing and Finance Research

Vol.8, No.1, pp.30-51, January 2020

Published by ECRTD-UK

Print ISSN: 2053-4086(Print), Online ISSN: 2053-4094(Online)

Data Normality Test Result

\begin{tabular}{|c|c|c|c|c|c|}
\hline variable | & obs & Pr (skewness) & Pr(Kurtosis) & adj chi2(2) & Prob>chi2 \\
\hline $\begin{array}{c}\text { mar_rtns } \\
\text { june_rtns } \\
\text { sept_rtns } \\
\text { dec_rtns } \\
\text { invt_days } \\
\text { pay_days } \\
\text { rec_days } \\
\text { curt_ratio } \\
\text { leverage } \\
\text { fsize }\end{array}$ & $\begin{array}{l}398 \\
398 \\
397 \\
398 \\
400 \\
400 \\
400 \\
400 \\
400 \\
400\end{array}$ & $\begin{array}{l}0.0000 \\
0.0000 \\
0.0000 \\
0.0000 \\
0.0000 \\
0.0000 \\
0.0000 \\
0.0000 \\
0.0000 \\
0.0036\end{array}$ & $\begin{array}{l}0.0000 \\
0.0000 \\
0.0000 \\
0.0000 \\
0.0000 \\
0.0000 \\
0.0000 \\
0.0000 \\
0.0000 \\
0.0051\end{array}$ & $\begin{array}{r}63.74 \\
\dot{5} \\
\dot{5} \\
14.2\end{array}$ & $\begin{array}{l}0.0000 \\
0.0000 \\
0.0000 \\
0.0000 \\
0.0000 \\
0.0000 \\
0.0000 \\
0.0000 \\
0.0000 \\
0.0008\end{array}$ \\
\hline
\end{tabular}

\section{Authors Computation 2019}

\section{Panel Regression Results}

However, to examine the cause-effect relationships between the dependent variables and independent variables as well as to test the formulated hypotheses, we used a panel regression techniques since the data had both time series (2010 to 2017) and cross-sectional properties (50 non-financial quoted companies). The panel data regression results obtained is presented and discussed below.

\begin{tabular}{|c|c|c|c|c|c|c|c|c|}
\hline (FI) & $\begin{array}{l}\text { FIXED EFFECT) } \\
\text { mar_rtns }\end{array}$ & $\begin{array}{l}\text { (RANDOM EFFECT) } \\
\text { mar_rtns }\end{array}$ & $\begin{array}{l}\text { (FIXED EFFECT) } \\
\text { june_rtns }\end{array}$ & $\begin{array}{c}\text { (RANDOM EFFECT) } \\
\text { june_rtns }\end{array}$ & $\begin{array}{l}\text { (FIXED EFFECT) } \\
\text { sept_rtns }\end{array}$ & $\begin{array}{l}\text { (RANDOM EFFECT) } \\
\text { sept_rtns }\end{array}$ & $\begin{array}{l}\text { (FIXED EFFECT) } \\
\text { dec_rtns }\end{array}$ & $\begin{array}{l}\text { (RANDON EFFECT) } \\
\text { deC_rtns }\end{array}$ \\
\hline invt_days & $\begin{array}{r}0.028 \\
(0.766)\end{array}$ & $\begin{array}{l}-0.038 \\
(0.497)\end{array}$ & $\begin{array}{r}0.033 \\
(0.717)\end{array}$ & $\begin{array}{c}0.048 \\
(0.440)\end{array}$ & $\begin{array}{l}-0.284^{2 *} \\
(0.002)\end{array}$ & $\begin{array}{l}-0.210^{* 88} \\
(0.000)\end{array}$ & $\begin{array}{l}-0.052 \\
(0.582)\end{array}$ & $\begin{array}{l}-0.045 \\
(0.423)\end{array}$ \\
\hline pay_days & $\begin{array}{r}0.074 \\
(0.474)\end{array}$ & $\begin{array}{r}0.105 \\
(0.113)\end{array}$ & $\begin{array}{r}-0.022 \\
(0.831)\end{array}$ & $\begin{array}{l}-0.041 \\
(0.575)\end{array}$ & $\begin{array}{l}0.297^{* *} \\
(0.003)\end{array}$ & $\begin{array}{l}0.260^{\mathrm{k} \times k} \\
(0.000)\end{array}$ & $\begin{array}{c}0.005 \\
(0.960)\end{array}$ & $\begin{array}{c}0.044 \\
(0.513)\end{array}$ \\
\hline rec_days & $\begin{array}{r}-0.105 \\
(0.242)\end{array}$ & $\begin{array}{r}-0.114 \\
(0.057)\end{array}$ & $\begin{array}{r}0.006 \\
(0.941)\end{array}$ & $\begin{array}{c}0.046 \\
(0.476)\end{array}$ & $\begin{array}{l}-0.081 \\
(0.350)\end{array}$ & $\begin{array}{l}-0.063 \\
(0.288)\end{array}$ & $\begin{array}{l}-0.002 \\
(0.982)\end{array}$ & $\begin{array}{l}-0.014 \\
(0.813)\end{array}$ \\
\hline curt_ratio & $\begin{array}{r}0.044 \\
(0.502)\end{array}$ & $\begin{array}{r}0.031 \\
(0.577)\end{array}$ & $\begin{array}{r}-0.009 \\
(0.882)\end{array}$ & $\begin{array}{l}-0.011 \\
(0.855)\end{array}$ & $\begin{array}{l}-0.060 \\
(0.349)\end{array}$ & $\begin{array}{l}-0.018 \\
(0.743)\end{array}$ & $\begin{array}{l}-0.038 \\
(0.569)\end{array}$ & $\begin{array}{l}-0.009 \\
(0.878)\end{array}$ \\
\hline Tever age & $\begin{array}{r}-0.119 \\
(0.187)\end{array}$ & $\begin{array}{r}-0.063 \\
(0.276)\end{array}$ & $\begin{array}{r}0.042 \\
(0.633)\end{array}$ & $\begin{array}{l}-0.004 \\
(0.949)\end{array}$ & $\begin{array}{l}-0.191^{*} \\
(0.030)\end{array}$ & $\begin{array}{l}-0.159 \times x \\
(0.006)\end{array}$ & $\begin{array}{l}-0.098 \\
(0.284)\end{array}$ & $\begin{array}{l}-0.117^{*} \\
(0.042)\end{array}$ \\
\hline fsize & $\begin{array}{l}-0.611^{*} \\
(0.031)\end{array}$ & $(0.029)^{0.115^{*}}$ & $\begin{array}{l}0.718^{* x} \\
(0.009)\end{array}$ & $\begin{array}{c}0.084 \\
(0.180)\end{array}$ & $\begin{array}{r}0.549 * \\
(0.047)\end{array}$ & $\begin{array}{c}0.024 \\
(0.643)\end{array}$ & $\begin{array}{c}0.389 \\
(0.172)\end{array}$ & $\begin{array}{c}0.092 \\
(0.081)\end{array}$ \\
\hline $\begin{array}{l}N \\
R-s q \\
\text { adj. } R-s q\end{array}$ & $\begin{array}{r}398 \\
0.031 \\
-0.125\end{array}$ & 398 & $\begin{array}{r}398 \\
0.023 \\
-0.134\end{array}$ & 398 & $\begin{array}{c}397 \\
0.057 \\
-0.095\end{array}$ & 397 & $\begin{array}{c}398 \\
0.011 \\
-0.148\end{array}$ & 398 \\
\hline $\begin{array}{l}\text { Prob F-statistics } \\
\text { Hausman Coef. }\end{array}$ & $0.0012^{*}$ & $\begin{array}{l}0.0059^{\star} \\
0.1228\end{array}$ & $0.0027^{*}$ & $\begin{array}{l}0.0004^{2} \\
0.3408\end{array}$ & $0.0027^{8}$ & $\begin{array}{l}0.0004^{\circ} \\
0.2259\end{array}$ & $0.0064^{*}$ & $\begin{array}{l}0.0017^{\circ} \\
0.8219\end{array}$ \\
\hline
\end{tabular}

Standardized beta coefficients; p-values in parentheses

${ }^{*} p<0.05, * 20<0.01$, ${ }^{* 2 \times} p<0.001$

The Prob. F-statistic value of (mar_rtns 0.0012, 0.0059), (june_rtns, 0.0027, 0.0004), (sept_rtns, 0.0027, 0.0004), (dec 0.0064 and 0.0017 ) for fixed and random effect models respectively shows 
European Journal of Accounting, Auditing and Finance Research

Vol.8, No.1, pp.30-51, January 2020

Published by ECRTD-UK

Print ISSN: 2053-4086(Print), Online ISSN: 2053-4094(Online)

that the four models are valid for drawing inference since they are all statistically significant at $5 \%$ respectively.

In testing for the cause-effect relationship between the dependent and independent variables in models 1 to 4, the two widely used panel data regression estimation techniques (fixed effect and random effect) were adopted. The table above presents the two panel data estimation techniques results (fixed effect and random effect). The results revealed differences in the magnitude of the coefficients, signs and the number of significant and insignificant variables. The estimation of the fixed effect panel regression is based on the assumption of no correlation between the error term and explanatory variables, while that of the random effect, considers that the error term and explanatory variables are correlated.

In selecting from the two panel logistic regression estimation results, the Hausman test was conducted and the test is based on the null hypotheses that the random effect model is preferred to fixed effect model. A look at the p-value of the Hausman test for all four models (0.1228), (0.3408) (0.2259) (0.8219) implies that we should accept the null hypothesis and reject the alternative hypothesis. This implies that random effect results tend to be more appealing statistically when compared to the fixed effect hence; we should adopt the results in drawing our conclusion and recommendations. Following the above, the discussion of the random effect results became imperative.

\section{Hypothesis 1: Liquidity has no Significant Relationship with Stock Returns Seasonality}

From the analysis, the variable of liquidity has no significant relationship with market returns seasonality although the relationship remained negative for most part of the year. Again, this finding seems unique and suggests that we should accept the null hypothesis which states that market liquidity is not related to stock market seasonality in Nigeria.

\section{Hypothesis 2: Account Payable Days has no Significant Relationship with Stock Market Returns Seasonality}

The regression result above reveals that account payable days (pay_days) has no significant relationship with stock returns seasonality in all seasons except in the third season which covers the months of July August and September with a coefficient of 0.260. It reveals a negative relationship with stock returns seasonality and it is statistically significant at one percent for the period under consideration due to the corresponding $\mathrm{P}$ value of 0.000 . Hence, the study concludes that account payable days has a significant effect on stock returns seasonality in Nigeria. This result, therefore, suggests that we should accept the alternative hypothesis which states that account payable days is significantly related to stock market seasonality in Nigeria.

\section{Hypothesis 3: Account Receivable Days has no Significant Relationship with Stock Market Returns Seasonality}

Interestingly, taking a cursory look at the relationship between account receivable days (rec_days) and stock market seasonality reveals that there is no significant relationship between stock market 
European Journal of Accounting, Auditing and Finance Research

Vol.8, No.1, pp.30-51, January 2020

Published by ECRTD-UK

Print ISSN: 2053-4086(Print), Online ISSN: 2053-4094(Online)

seasonality and account receivable days in all the seasons which covers the months of January to December. However, the finding shows a negative relationship all through the second half of the year. This finding seems unique and suggests that we should accept the null hypothesis which states that account receivable day is not related to stock market return seasonality in Nigeria.

\section{Hypothesis 4: Inventory Days has no Significant Relationship Stock Market Returns Seasonality}

The regression result above reveals that inventory days (invent_days) has no significant relationship with stock returns seasonality for all seasons except in the third season which covers the months of July August and September with a coefficient of -0.210 . It reveals a negative relationship with stock returns seasonality and it is statistically significant at one percent for the period under consideration due to the corresponding $\mathrm{P}$ value of 0.000 . Hence, the study concludes that Inventory days has a significant effect on stock returns seasonality and suggests that we should accept the alternative hypothesis which states that inventory days is significantly related to stock market seasonality in Nigeria

Hypothesis 5: Firm Leverage has no Significant Relationship with Stock Returns Seasonality Following the regression result above, we find that firm leverage (leverage) has no significant relationship with stock returns seasonality for all the seasons except in the third and fourth seasons which covers the months of July to December. However, while the result showed a negative relationship, it was also found to be significant at $5 \%$ in the third season and $1 \%$ in the fourth season. This result therefore, suggests that we should accept the alternative hypothesis which states that leverage is significantly related to stock market seasonality in Nigeria.

\section{Hypothesis 6: Firm Size has no Significant Relationship Stock Market Returns Seasonality} Following the regression result above, it is revealed that firm size (fsize) has no significant relationship with stock returns seasonality for all the seasons except in the first season which covers the months of January to March. The coefficient of 0.115 shows a positive relationship with stock returns seasonality and it is statistically significant at 5\% percent for the period under consideration due to the corresponding $\mathrm{P}$ value of 0.029 . Hence, the study concludes that firm size has a significant effect on stock returns seasonality in Nigeria. This result, therefore, suggests that we should accept the alternative hypothesis which states that inventory days is significantly related to stock market seasonality in Nigeria.

\section{DISCUSSION OF FINDINGS}

It is generally accepted that liquidity, is an important attribute of assets which influence investors' portfolio investment decisions. Since investors care about expected holding period, hence, less liquid (and more costly to trade) assets need to provide higher gross returns compared to more liquid assets. However, the finding from this study negates the findings obtained in (Baker \& Stein 2004) which show that high liquidity is a symptom of the fact that the market is dominated with irrational investors, consequently overvalued. It suggests that market liquidity is not an important 
determinant of stock returns in Nigeria. Information asymmetry may possibly be a bane in the Nigerian Stock Exchange market that deprives investors from making informed investment decisions. Furthermore, the result also negates the findings of Easley \& O'Hara (2004) and Easley et al. (2002) whose studies documents a strong positive support for January effect. The result obtained from this study does not conform to that of Jacoby et al. (2000) Haugen and Baker (1996). Estrada (2000) (Fang et al. 2009) (Khanna \& Sonti 2004; but agrees with (Eleswarapu \& Reinganum 1993), whose study did not find any evidence of seasonality in liquidity premium.

The findings of the study indicate that the variable of account payable day had statistical significant difference with variations across the months (especially in the months of July to September). This is an indication that an improvement in working capital management with respect to making prompt payment as bills fall due will significantly improve on shareholders wealth via increase in share returns. The findings agrees with (Lazaridis \& Tryfonidis 2006) and (Kithii 2008) but negate the findings of (Raheman and Nasr 2007). The variable of inventory day indicates that an improvement in inventory management would cause stock returns to react negatively. This is a characteristic of an emerging market as documented by (Chordia, et al 2001). The result from this study aligns with (Dogan 2013) who identified a positive relationship between size indicators of total assets, total sales and number of employees and financial returns of firms. Therefore an increase in size of a firm would influence the increase in stock returns of a firm and vice versa. We note that the significant relationship between firm size and stock market returns was found only in the first season which strongly supports the January effect hypothesis. This finding is inconsistent with that of (Reinganum 1983) who found that small firms outperformed larger firms; especially in the first few trading days in January and the evidence show that tax selling hypothesis was found to be the main reason for the anomaly.

We find that the variable of leverage supports the findings of (Ching, Novazzi and Gerab 2011) who observed that by managing debt ratio effectively business managers can create more profits for their companies which in turn translate to higher stock returns. The result suggests that optimal debt utilization will benefit shareholders around the second half of the year which is July to September.

\section{Summary of Findings}

The main objective of this study is to reveal the relationship that exists between working capital management, market liquidity and stock market return seasonality among non-financial listed companies in Nigeria. The study employed panel data collected from various related annual financial statements for the period of 2010 to 2017

However, the list below makes up the key findings from the study:

1. This study reveals that inventory days has no significant relationship with stock market returns seasonality for all seasons except in the third season which covers the months of July August and September 
European Journal of Accounting, Auditing and Finance Research

Vol.8, No.1, pp.30-51, January 2020

Published by ECRTD-UK

Print ISSN: 2053-4086(Print), Online ISSN: 2053-4094(Online)

2. Account payable days was found to have no significant relationship with stock market returns seasonality for all seasons except in the third season which covers the months of July August and September

3. The relationship between account receivable days and stock market returns seasonality reveals that there is no significant relationship between stock market seasonality and account receivable days in all the seasons which covers the months of January to December

4. More specifically the variable of market liquidity is revealed to be insignificantly related with market returns seasonality even though the relationship remained negative for the most part of the year.

5. Leverage has no significant relationship with stock market seasonality for all the seasons except in the third and fourth seasons which covers the months of July to December.

6. Firm size has no significant relationship with stock returns seasonality for all the seasons except in the first season which covers the months of January to March.

\section{CONCLUSION}

The study intends to verify the relationship working capital management, firm liquidity and stock market seasonality among quoted firms in Nigeria. Working capital management characteristic variables of inventory day, account payable day, account receivable day, and some firm characteristic variables of liquidity, leverage and firm size was adopted for the study. Data set relating to the variables from fifty (50) quoted non-financial companies on the Nigerian stock exchange was employed in this study. The study adopted a more appropriate analysis technique of panel ordinary least square regression which is best used to address studies where time and cross section effects are present in the data set. (Gujarati 2006)

Consequent upon the results obtained from the study we found out that manager can create profits for their companies by keeping each different component of working capital: accounts payables and inventory day at an optimum level. Specifically, the finding suggests that market liquidity cannot predict stock market returns irrespective of the season of the year. It lends credence to the efficient market theory which holds that share markets prices are unpredictable and as such cannot be forecasted. It disallows the ability of an investor to predict on the particular times that will result in them gaining the most. Hence the market is efficient due to this randomness and will rapidly respond to any information or anomalies presented to it.

\section{Recommendations}

Working capital management and stock returns nexus is an interesting topic on its own merits. By using a new dataset, the paper attempts to provide the answer to the question of whether specific working capital components and market liquidity affects stock market seasonality in Nigeria. Specific among the finding from this study is that liquidity do not affects stock returns during the period under investigation. This finding is inconsistent with most of apriori literature. The policy implications of the findings of the paper are twofold. Firstly, liquidity may not be an important factor in asset pricing. Therefore, policy makers in emerging market such as Nigeria should ease 
European Journal of Accounting, Auditing and Finance Research

Vol.8, No.1, pp.30-51, January 2020

Published by ECRTD-UK

Print ISSN: 2053-4086(Print), Online ISSN: 2053-4094(Online)

the barriers for firms to enhance liquidity. Policy makers with respect to the Nigerian context should lower the trading costs for traders to increase liquidity. Consequently, the study recommends that there should be proper inventory management system in Nigeria to avoid working capital mismanagement. Management of quoted companies should put in place working capital management systems so as to increase stock returns. The study further recommends that companies should engage in relationship with those suppliers who allow long credit time period and those customers who are consistent in making short payment period.

\section{Suggestions for Further Research}

In view of the limitations that constrained this study, a number of issues which might possibly influence the outcome of the investigation were not explored. In view of this, it is suggested that further studies which would capture all non-financial companies listed on the Nigerian Stock Exchange or segregate these studies on industry basis, should be attempted. The number of control variables could also be increased for a more robust model. Moreover, further research can be conducted on the same topic in different countries so that working capital management policies can be compared between developing countries and developed countries in order to determine more correct management policies.

\section{REFERENCES}

Acharya V. and L.H. Pedersen (2005), 'Asset Pricing with Liquidity Risk', Journal of Financial Economics, 77: 375-410.

Agarwal, P. (2009). Institutional Ownership, Liquidity and Liquidity Risk Available at http://ecommons.cornell.edu/bitstream/1813/13840/1/Agarwal,\%20Prasun.pdf

Agrawal, A. and K. Tandon, (1994), 'Anomalies or Illusions? Evidence from Stock Markets in Eighteen Countries,' Journal of International Money and Finance, 13: 83-106

Ajibola, A., and Nwakanma P. C., (2014) Detecting Market Anomalies: Do Evidences hold in Nigeria? International Review of Management and Business Research, 2: 1128-1138.

Aitken, M. \& Comerton-Forde, C. 2003, 'How should liquidity be measured?', Pacific- Basin Finance Journal, vol. 11, no. 1, pp. 45-59.

Alagidede, P., (2008). Day-of-the-week seasonality in African stock markets Applied Financial Economics Letters, 2: 115-120

Al-Deehani, TM, (2006), 'Seasonality as an unobservable component: The case of Kuwait stock market', Applied Financial Economics, 16(6): 471-478.

Al-Hajieh, H, Redhead, K and Rodgers, T, (2011), 'Investor sentiment and calendar anomaly effects: A case study of the impact of Ramadan on Islamic Middle Eastern markets', Research in International Business and Finance, 25(3): 345-356.

Aly, H., Mehdian, S., and Perry, M. J. (2004). An Analysis of Day-of-the-Week Effects in the Egyptian Stock Market International Journal of Business, 3(9):301-308

Amihud, Y. and Mendelson, H. (1986), 'Asset pricing and the bid-ask spread', Journal of Financial Economics, 17(2): 223-249. 
European Journal of Accounting, Auditing and Finance Research

Vol.8, No.1, pp.30-51, January 2020

Published by ECRTD-UK

Print ISSN: 2053-4086(Print), Online ISSN: 2053-4094(Online)

Ariel, R. A. (1987). A monthly effect in stock returns. Journal of Financial Economics, 18(1), 161-174.

Bammeri \& Dehani, N. (2013). The effect of capital management on stock returns of accepted companies in Tehran Stock Exchange. European Online Journal of Natural and Social Sciences, 2(3), 1061-1069.

Barsky, R.B and J. B. Delong (1991), "Forecasting Pre-World War I Inflation: The Fisher Effect and the Gold Standard," Quarterly Journal Of Economics 106 (3): 815-36.

Beaver, W.H. \& Ryan, S.G. 2000, 'Biases and lags in book value and their effects on the ability of the book-to-market ratio to predict book return on equity', Journal of Accounting Research, vol. 38, no. 1, pp. 127-148.

Begg, S.F and Rudiger D.D. (1987) Economics, 2nd Edition, McGraw Hill

Bekaert, G., and Harvey, C. R. (2000). Foreign Speculators and Emerging Equity Markets Journal of Finance 55: 565-613.

Berument, H., and Kiymaz, H. (2001). The day of the week effect on stock market volatility Journal of economics and finance, 25(2), 181-193

Benson , R., Y Faff, D.,M. and Smith O., H. (2015) Injecting Liquidity into Liquidity Research: Pacific-Basin Finance Journals 35 October 2015 DOI: 10.1016/J.Pacfin.2015.100.01

Bhattacharya, U., Daouk, H., Welker, M. 2003. The World Price of Earnings Opacity. The Accounting Review 78, 641-678

Białkowski, J, Etebari, A and Wisniewski, TP, (2012), 'Fast profits: Investor sentiment and stock returns during Ramadan', Journal of Banking and Finance, 36(3): 835-845.

Booth, DG and Keim, DB, (2000), 'Is there still a January effect? ', in DB Keim \& WT Ziemba (eds), Security Market Imperfections in Worldwide Equity Markets, Cambridge University Press, New York.

Bouman, S., and Jacobsen, B. (2002). The Halloween Indicator, "Sell in May and Go Away": Another Puzzle. American Economic Review, 92(5): 1618-1635.

Bouman, S., and Jacobsen, B. (2002). The Halloween indicator,"Sell in May and go away": Another puzzle. American Economic Review, 92: 1618-1635

Brennan, M.J. and Subrahmanyam, A. (1996), 'Market microstructure and asset pricing: On the compensation for illiquidity in stock returns', Journal of Financial Economics, 41(3): 441464.

Brown, P., Keim, D. B., Kleidon, A. W., and Marsh, T. A. (1983) Stock return seasonalities and the tax-loss selling hypothesis: Analysis of the arguments and Australian evidence. Journal of Financial Economics, 12(1): 105-127.

Butler, AW, Grullon, G and Weston, JP, (2005), 'Stock market liquidity and the cost of issuing equity', Journal of Financial \& Quantitative Analysis, 40(2): 331-348.

Chan, MWL, Khanthavit, A and Thomas, H, (1996), 'Seasonality and cultural influences on four Asian stock markets', Asia Pacific Journal of Management, 13(2): 1-24.

Charles, A. (2010). The day-of-the-week effects on the volatility: The role of the asymmetry. European Journal of Operational Research, 202(1): 143-152. 
European Journal of Accounting, Auditing and Finance Research

Vol.8, No.1, pp.30-51, January 2020

Published by ECRTD-UK

Print ISSN: 2053-4086(Print), Online ISSN: 2053-4094(Online)

Chen, H., and Singal, V. (2003). Role of speculative short sales in price formation: The case of the weekend effect. The Journal of Finance, 58(2): 685-706.

Chirchir, D (2012) The relationship between share prices and interest rates: evidence from Kenya. Unpublished MBA Project, University of Nairobi

Cho, Y. H., Linton, O., and Whang, Y. J. (2007) Are there Monday effects in stock returns: A stochastic dominance approach Journal of Empirical Finance, 14(5): 736-755.

Chordia, T, Roll, R and Subrahmanyam, A, (2001), 'Market liquidity and trading activity', Journal of Finance, 56(2): 501-530.

Chordia, T, Roll, R and Subrahmanyam, A, (2008), 'Liquidity and market efficiency', Journal of Financial Economics, 87(2): 249-268

Chordia, T., Roll, R., and Subrahmanyam, A. (2003) Determinants of Daily Fluctuations in Liquidity and Trading Activity Cuadernos de Economia, 40(121): 728-751.

Chordia, T., Sarkar, A., and Subrahmanyam, A. (2005) An Empirical Analysis of Stock and Bond Maket Liquidity.The Review of Financial Studies, 18(1): 85-129.

Cross, F. (1973). The behavior of stock prices on Fridays and Mondays Financial analysts' journal, 67-69

Cumming, D, Johan, S and Li, D, (2011), 'Exchange trading rules and stock market liquidity', Journal of Financial Economics, 99(3): 651-671.

Datar, V.T., Y. Naik, N. and Radcliffe, R. (1998), 'Liquidity and stock returns: An alternative test', Journal of Financial Markets, 1(2): 203-219.

Draper, P., \& Paudyal, K. (1997). Microstructure and Seasonality in the UK Equity Market Journal of Business Finance and Accounting, 24(7):1177-1204.

Dong H.P., and Jyh-tay Su ., (2010),'The Relationship between working capital management and profitability: A Viet name case".

Easley, D., Hvidkjaer, S. and O'Hara, M. (2002), 'Is information risk a determinant of asset returns?', Journal of Finance, 57(5): 2185-2221.

Eleswarapu, V.R. and Reinganum, M.R. (1993), 'The seasonal behavior of the liquidity premium in asset pricing', Journal of Financial Economics, 34(3): 373-386.

Enweremadu D.U. (2013) Nigeria as an emerging economy? Making sense of expectations, South African Journal of International Affairs, 20(1):57-77.

Falope O. and Ajilore O. 2009. Working capital management and corporate profitability: Evidence from panel data analysis of selected quoted companies in Nigeria. Research Journal of Business Management, Vol3 No 3, pp.73-84 (ISSN: 1819-1932)

Fama, E.F. \& French, K.R. 1992, 'The Cross-Section of Expected Stock Returns', The Journal of Finance, vol. 47, no. 2, pp. 427-465.

Foster, F. D., and Viswanathan, S. (1993). Variations in Trading Volume, Return Volatility, and Trading Costs: Evidence on Recent Price Formation Models. The Journal of Finance, 48(1): 187-211.

French, K. R. (1980). Stock returns and the weekend effect. Journal of financial economics, 8(1): 55-69 
European Journal of Accounting, Auditing and Finance Research

Vol.8, No.1, pp.30-51, January 2020

Published by ECRTD-UK

Print ISSN: 2053-4086(Print), Online ISSN: 2053-4094(Online)

Fujimoto, A. (2003). Macroeconomic Sources of Systematic Liquidity Working Paper, Yale University, pp. 1-50

Gibbons, M., \& Hess, P. (1981). Day of the week effects and asset returns Journal of Business, October, 579- 596

Goldstein, MA and A. Kavajecz, K, (2000), 'Eighths, sixteenths, and market depth: changes in tick size and liquidity provision on the NYSE', Journal of Financial Economics, 56(1): 125149.

Goyenko, R. Y., \& Ukhov, A. D. (2009) Stock and Bond Market Liquidity: A Long-Run Empirical Analysis. Journal of Financial and Quantitative Analysis, 44: 189-212.

$\mathrm{Gu}$, A. Y. (2003). The declining January effect: evidences from the US equity markets. The Quarterly Review of Economics and Finance, 43(2): 395-404.

Hameed, A., Kang, W., and Viswanathan, S. (2010) Stock Market Declines and Liquidity The Journal of Finance, 65(1): 257-293.

Harris, L, (2003), 'Trading and Exchange Market Microstructure for Practitioners', Oxford University Press, Inc., New York.

Hasbrouck, J. (2005). Trading costs and returns for US equities: estimating effective costs from daily data. Journal of Finance, 64: 1445-1477.

Haugen, R. A., and Lakonishok, J. (1987) The incredible January effect: The stock market's unsolved mystery. Dow Jones-Irwin

Hong, H., and Yu, J. (2009) Gone Fishing': Seasonality in Trading Activity and Asset Prices Journal of Financial Markets, 12(4): 672-702.

Hong, H., and J. Yu, 2005, Gone fishing': Seasonality in speculative trading and asset prices, working paper.

Hornbrink \& Bratland, (2013). An Empirical Study of the Relationship between Working Capital Policies and Stock Performance in Sweden, Umea School of business management.

Jacobsen, B., and Visaltanachoti (2009). The Halloween effect in US sectors Financial Review, 44(3): 437-459.

Kale, JR and Loon, YC, (2011), 'Product market power and stock market liquidity', Journal of Financial Markets, 14(2): 376-410.

Keim, D. B. (1983). Size-related anomalies and stock return seasonality: Further empirical evidence. Journal of Financial Economics, 12(1): 13-32.

Keim, DB and Stambaugh, RF, (1984), 'A further investigation of the weekend effect in stock returns', Journal of Finance, 39(3): 819-835.

Keim, DB, (1983), 'Size-related anomalies and stock return seasonality: Further empirical evidence', Journal of Financial Economics, 12(1): 13-32.

Kohers, G., Kohers, N., Pandey, V., \& Kohers, T. (2004) The disappearing day-of-the-week effect in te world's largest equity markets Applied Economics Letters, 11(3): 167-171

Kramer, L.A., M. Kamstra, and R. DeGennaro, (2005), Seasonal variation in bidask spreads, working paper.

Kuria, A. M., and Riro, G. K. (2013) Stock market anomalies: A study of seasonal effects on average returns of Nairobi securities exchange. Research Journal of Finance and Accounting, 4(7): 207-215. 
European Journal of Accounting, Auditing and Finance Research

Vol.8, No.1, pp.30-51, January 2020

Published by ECRTD-UK

Print ISSN: 2053-4086(Print), Online ISSN: 2053-4094(Online)

Lakonishok, J., and S. Smidt, (1988), 'Are Seasonal Anomalies Real? A Ninety Year Perspective', Review of Financial Studies, 1: 403-425.

Levine, R. 1996, 'Stock Markets: A Spur to Economic Growth', Finance \& Development, vol. March.

Levine, R. and Zervos, S. (1998), 'Stock markets, banks, and economic growth', American Economic Review, 88(3): 537-558.

Madhavan, A, (2000), 'Market microstructure: A survey', Journal of Financial Markets, 3(3): 205258.

Marshall, BR and Visaltanachoti, N, (2010), 'The other January effect: Evidence against market efficiency?', Journal of Banking \& Finance, 34(10): 2413-2424.

Mehdian, S., and Perry, M. J. (2002) Anomalies in US equity markets: A re-examination of the January effect.Applied Financial Economics, 12(2): 141-145

Moller, N., \& Zilca, S. (2008). The evolution of the January effect Journal of Banking \& Finance, 32(3), 447-457.

Ogusoy, CB and Güven, S, (2004), 'Holy days effect on Istanbul stock exchange', Journal of Emerging Market Finance 3(1): 63-75.

O'hara, M, (2004), Liquidity and Financial Market Stability, Working Papers Research Series 55, National Bank of Belgium

Oladayo O. (2015) The January and Monday effect or the lack thereof, Mathematical Theory and Modeling, 5(4):163-167

Olowe, R. A., (2011). Exchange Rate Volatility, Global Financial Crisis and the Day-of-the- Week Effect KJBM, 3

Osarumwense, O.I. (2015) Day-of-the-week effect in the Nigerian Stock Market Returns and Volatility: Does the Distributional Assumptions Influence Disappearance? European Financial and Accounting Journal, (10)4: 33-44

Osazevbaru, H. O., Oboreh, J., (2014). The "Monday Effect" in Nigerian Stock Market: Evidence and Implication. Journal of Social Sciences and Public Policy, 1: 1-8.

Pastor, L. and R. F. Stambaugh (2003), 'Liquidity Risk and Expected Stock Returns', Journal of Political Economy, 111: 642-685.

Raj, M., and Thurston, D. (1994), "January or April? Tests of the turn-of-the-year effect in the New Zealand stock market", Applied Economic Letters, 1:81-93

Reinganum M.R., (1983) The anomalous stock market behavior of small firms in January: Empirical tests for tax-loss selling effects, Journal of Financial Economics, 12(1): 89-104.

Reilly, F.K. and Brown, K.C., 2003. Investment Analysis and Portfolio Management. Ohio United States of America: Thomson South-Western.

Ritter, J. R. (1988). The buying and selling behavior of individual investors at the turn of the year The Journal of Finance, 43(3):701-717.

Roll, R, (1983), 'Vas ist das?', The Journal Of Portfolio Management, 9(2): 18-28.

Rozeff, M. S., and Kinney Jr, W. R. (1976) Capital market seasonality: The case of stock returns. Journal of Financial Economics, 3(4): 379-402. 
Seyyed, FJ, Abraham, A and Al-Hajji, M, (2005), 'Seasonality in stock returns and volatility: The Ramadan effect', Research in International Business and Finance, 19(3): 374-383.

The Nigerian Stock Exchange 2017 Market Recap and Outlook for 2018

Umar, B. N., (2013). The Day-of-the-week effect on stock market returns and volatility: Evidence from Nigeria and South Africa. MPRA Paper No. 48076.

Van Ness BF, Van Ness RA and Warr, RS, (2005), 'Nasdaq trading and trading costs: 1993-2002', Financial Review, 40(3): 281-304.

Wachtel, S. B. (1942). Certain observations on seasonal movements in stock prices Journal of Business of the University of Chicago, 184-193

WDI. (2016, April 4th). Trading Economics Global Macro Models and Analysts Expectations Retrieved April Wednesday, 2016, From Trading Economics Website: www.Tradingeconomics.com

William, J.M. (2002) Forecasting the NYSE composite index with technical analysis, pattern recognizer, neural network and genetic algorithm: a case study in romantic decision support Decision Support Systems, 32(4): 361-67

Zariyawati, A, M., Annuar, N, M., Taufiq, H and Rahim, A, S, A. (2009)," Working capital management and corporate performance: Case of Malaysia", Journal of Modern Accounting and Auditing. Vol.5 No.11 